\title{
Environmental and health impact of potentially harmful elements distribution in the Panyam (Sura) volcanic province, Jos Plateau, Central Nigeria
}

\author{
U. A. Lar $\cdot$ R. B. Gusikit
}

Received: 19 August 2013/Accepted: 11 February 2015/Published online: 24 February 2015

(C) The Author(s) 2015. This article is published with open access at Springerlink.com

\begin{abstract}
The Panyam volcanic province is a plateau covering a superficial area of about $1200 \mathrm{~km}^{2}$, dotted by a number of dormant volcanoes forming prominent landmarks above the host continental gneiss-migmatite-granite rocks and stretching for about $12 \mathrm{~km}$. The volcanism is basaltic, characterized by alkaline-calc-alkaline compositions. Large population of people live and depend on the volcanic environment for potable water and agriculture, most of whom display various forms of health problems ranging from dental caries, goitre, podoconiosis, etc. This study therefore seeks to evaluate the concentration levels of potentially harmful elements (PHEs) in the various components of the volcanic environment and their relationship with the inherent human health problems in the area. Volcanic soils and underground waters (springs/boreholes waters) were collected from within the volcanic province for the analysis of major cations and anions. Samples of the volcanic soils were analyzed for the following heavy elements; $\mathrm{Be}, \mathrm{Co}, \mathrm{Cr}, \mathrm{Cu}, \mathrm{As}, \mathrm{Cd}, \mathrm{Pb}, \mathrm{Sb}, \mathrm{Se}, \mathrm{V}$, and $\mathrm{Zn}$. Water samples were analyzed for the major cations $\mathrm{Mg}^{2+}$, $\mathrm{Ca}^{2+}, \mathrm{Na}^{+}$and $\left.\mathrm{K}^{+}\right)$and major anions $\left(\mathrm{NO}_{3}^{2-}, \mathrm{SO}_{4}^{2-}, \mathrm{Cl}^{-}\right.$, $\mathrm{HCO}_{3}^{-}$and $\mathrm{F}^{-}$) to determine their hydrogeochemical characteristics so as to identify the major sources of the cations and anions and factors controlling their distribution. The volcanic soils display mean values in $\mathrm{Be}, \mathrm{Co}, \mathrm{Cr}, \mathrm{Ni}$, $\mathrm{Pb}, \mathrm{Sb}$ and $\mathrm{Se}$ above the baseline regional values with enrichment factors $(\mathrm{EF})(2 \leq \mathrm{EF} \leq 5)$ indicating moderate
\end{abstract}

Electronic supplementary material The online version of this article (doi:10.1007/s12665-015-4178-0) contains supplementary material, which is available to authorized users.

U. A. Lar $(\varangle)$ · R. B. Gusikit

Department of Geology, University of Jos, Jos, Nigeria

e-mail: ualexanderlar@yahoo.co.uk to strong enrichment in the volcanic soils. Contrarily, there is clear impoverishment of $\mathrm{As}, \mathrm{Cd}, \mathrm{Cu}, \mathrm{V}$ and $\mathrm{Zn}$ in the volcanic soils relative to the baseline values $(0 \leq \mathrm{EF} \leq 2)$. Except for $\mathrm{Ni}$ and $\mathrm{Se}$ which seem to have contaminated the volcanic soils [pollution load index $(\mathrm{PLI})>1$ ], these other elements $\mathrm{As}, \mathrm{Be}, \mathrm{Cd}, \mathrm{Cr}, \mathrm{Cu}, \mathrm{Pb}, \mathrm{Sb}, \mathrm{V}$ and $\mathrm{Zn}$ with PLI $<1$ did not, possibly suggesting little or no anthropogenic input. The rare earth elements (REEs) are equally enriched in the volcanic soils and like most of the other PHEs, they must have been scavenged and co-precipitated with $\mathrm{Fe}$ during the weathering of the parent basaltic rock. The significantly lower $\mathrm{La} / \mathrm{Ce}$ ratios $(0.30-0.57)$ in the volcanic soils attest to the moderate to slightly severe intensity of weathering the parent basaltic rock was subjected to. The waters are predominantly $(80 \%)$ of $\mathrm{Ca}-\mathrm{Mg}-\mathrm{HCO}_{3}$ type with the remaining $20 \%$ of $\mathrm{Na}-\mathrm{K}-\mathrm{HCO}_{3}$ type suggesting a control by water-rock alteration process from the host granitic basement and the overlying basaltic rocks. The fluoride content in all the water sources is positively correlated with the contents of $\mathrm{Mg}^{2+}, \mathrm{Na}^{+}$, and $\mathrm{K}^{+}$suggesting a similar source and geochemical process. Tooth decay, a common tooth disease conditions in the volcanic province, could be linked to the low F content in the waters.

Keywords Volcanoes - Basaltic rocks - PHEs - Human health $\cdot$ Jos Plateau $\cdot$ Panyam volcanic line

\section{Introduction}

The Panyam volcanic province, situated on the Jos Plateau Central Nigeria, consists of seven major dormant volcanoes namely: Ndai Volcano (referred to as Wushik volcano), Amshal Volcano (referred to as Kogul Volcano), Dutsin 
Volcano, Kerang Volcano, Timgya'ras Volcano, Ampang Volcano (referred to as Mufil Volcano), and Pidong Volcano or Pidong Volcanic Crater Lake; all aligned along NNW-SSE trend (Lar et al. 2007) and stretching for a distance of about $10 \mathrm{~km}$ (Figs. 1, 2). It is the second largest volcanic province in Nigeria with a superficial area of $1200 \mathrm{~km}^{2}$ after Biu volcanic province with an area of about $2500 \mathrm{~km}^{2}$ (Lar et al. 2007; Lar and Usman 2012). None of these volcanoes has erupted in time immemorial. There is sufficient evidence to suggest that the lava that gave rise to these edifices extruded through a series of linear megastructures in the host Basement migmatite-gneisses complex (Tsalha et al. 2014). The volcanoes occur either as large single cones or as composite cones usually with very large craters (up to $1 \mathrm{~km}$ ). The volcanic edifices are built of mainly basaltic scoria and pyroclastics riddled with voids filled with phenocrysts of olivine, clinopyroxene or garnet. Mineralogically, the fresh basaltic rocks consist of olivine, pyroxene (augite), plagioclase (labradorite) and accessory minerals such as ilmenite/magnetite and garnet displaying the same characteristics as those of the Benue trough and that of the Cameroon volcanic line (Lar and Tsalha 2005).

Recent Ar-Ar dating of similar volcanic edifices on the Jos Plateau has recorded ages of spanning from 1.95 to 1.34 Ma (MacLeod et al. 1971; Lar et al. 2007) ascribing their emplacement to the Pleistocene epoch. The high proportion of fragments of the host basement rocks in the pyroclastic pile in addition to the highly vesicular nature of

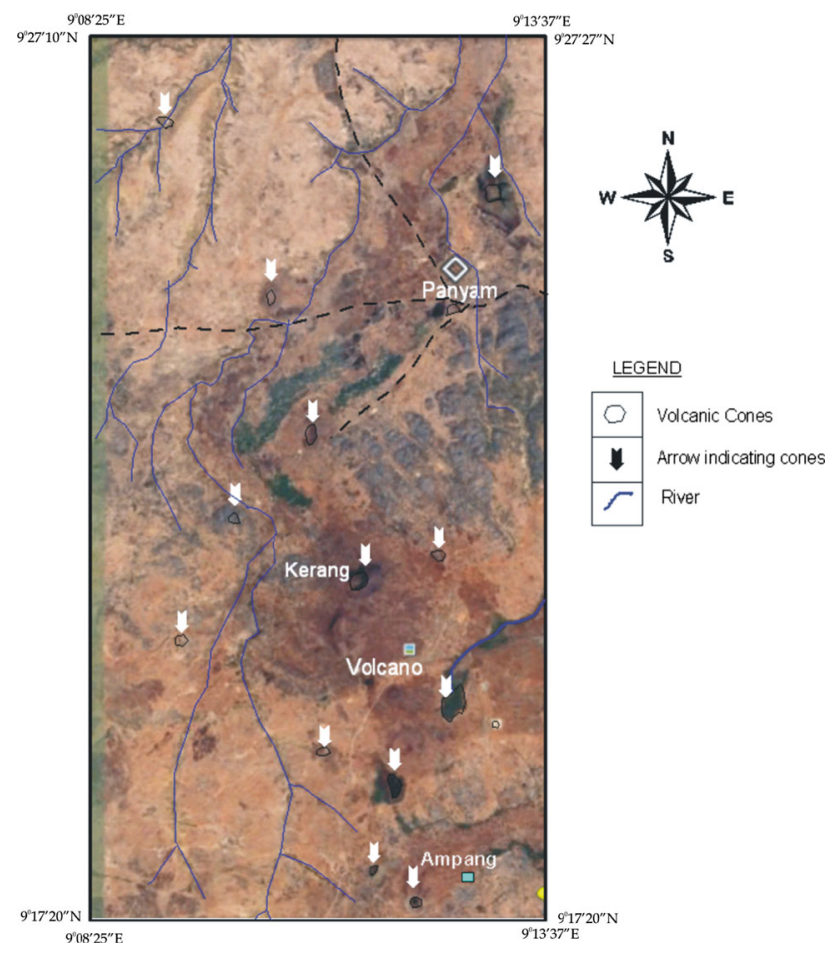

Fig. 1 Satellite image of Panyam volcanic province

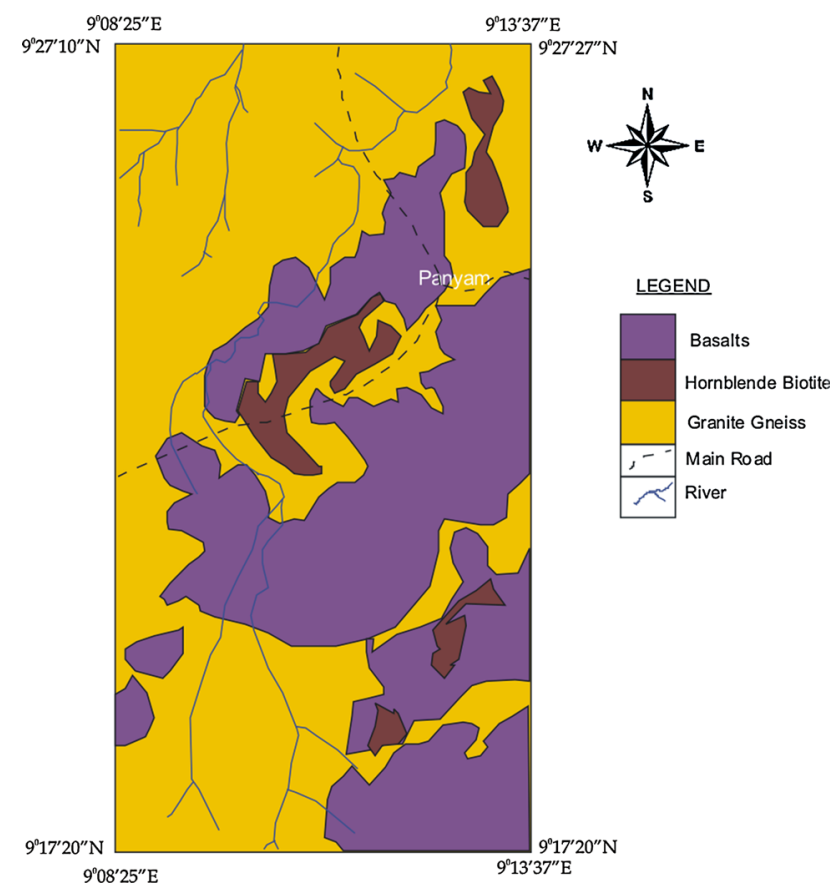

Fig. 2 Geological map of Panyam volcanic province (modified from the satellite image)

the basaltic materials in the volcanic edifice suggest violent eruptions in most cases (Lar et al. 2007). The basalts have been affected by various degrees of weathering where they have been decomposed to lateritic soils. However, fresh unweathered basaltic lava flows can be traced along river channels, for example at Ajing, Bwonpe, Kerang, Pang and Kogul (Panyam) (Gusikit 2010).

Volcanic eruption process is known to bring along with it chemical elements from depth (mantle) which ordinarily are not abundant on the earth's surface. Thus, soils developed from these basalt piles contain concentrations of heavy metals which could be released and redistributed into the soils, surface and ground water through the weathering processes.

In most soils developed on basalts, high baseline values of heavy metals such as $\mathrm{Pb}, \mathrm{Zn} \mathrm{Sb}, \mathrm{Hg}, \mathrm{Cd}, \mathrm{Cr}$ and $\mathrm{Cu}$ have been recorded (Cicchella et al. 2005), however, this has been attributed partly to anthropogenic contribution due to a long period of human activity in the area (Cortizas et al. 2003). Certain forms of diseases such as cancer especially in males have also been reported to be higher than the regional average on the Ischia volcanic Island attributable to high radioactivity (Fratinin et al. 2006). Human exposure of unprotected feet to high concentrations of $\mathrm{Zr}$ and $\mathrm{Be}$ in volcanic soils which have the ability to induce granuloma in the lymphoid tissue of man is a causal factor in the development of podoconiosis (Frommel et al. 1993). Goiter prevalence in the Kenyan Rift African valley, an active volcanic environment, has been linked to iodine 
deficiency in drinking water (3.7-24 $\mu \mathrm{g} / \mathrm{l})$ from wells and surface water sources in the area (Davies 1995, 2008). Recent studies in the Biu Plateau Volcanic province, North Eastern Nigeria have revealed high values of $\mathrm{As}, \mathrm{Pb}, \mathrm{Sb}$ and Se in drinking water sources and linking over-exposure to essentially Arsenic to various forms nail of deformities and skin hyperpigmentation (Lar and Usman 2012).

This paper therefore attempts to assess the concentration levels of some potentially harmful elements and the possible human health impact on the human population who live and are engaged in subsistence agriculture in the fertile volcanic soil of the Panyam volcanic province.

\section{Materials and methods}

Field methods

Seven soils were collected from the volcanic province each from a square grid of a $20 \mathrm{~m} \times 20 \mathrm{~m}$ dimension in accordance with IGCP 259 recommended practice (Darnley et al. 1995). Using a soil auger, four holes at the corner of the square grid (field) were dug up to $30 \mathrm{~cm}$ (below the $\mathrm{A}_{0}$ horizon) and a composite soil sample collected from each hole. The four sub-samples were homogenized, and about $400 \mathrm{~g}$ was collected and stored in a plastic container for chemical analysis. Eleven samples of potable water were collected: four from boreholes and seven from springs each in a 200-ml capacity. The bottles were pre-soaked in deionized water over the night to eliminate contaminants. At each sampling point, each bottle was rinsed with the sample water to be collected three times before it was finally collected. The samples were acidified with two drops of concentrated nitric acid to prevent fungal growth and the adsorption of the analytes to the walls of the sample container. Borehole water was pumped out for several minutes to ensure that only fresh water oozing out from the aquifer is collected. For the spring's water, the samples were collected close to the emission points.

Sample preparations

The soil samples were pulverized using an agate mortar and pestle to a size below 2-mm mesh. $50 \mathrm{~g}$ of each sample was weighed and stored in airtight glass vials for shipment for geochemical analysis. Polyethylene sampling bottles of 30-ml capacity were rinsed with distilled water before being used for sample collection. Each of the water sample bottle was tightly sealed and stored in a refrigerator at a temperature of about $23{ }^{\circ} \mathrm{C}$ for a week before shipment for analysis. Laboratory procedures were in accordance with the standard test procedures. Geochemical analysis of both water and soil samples was done at the Activation
Laboratories, Canada. In the laboratory, the soil samples were dried at a low temperature of $30-35{ }^{\circ} \mathrm{C}$ for $6-12 \mathrm{~h}$ to avoid loss of $\mathrm{Se}, \mathrm{Hg}$, and As. A 0.5-g sample was digested in aqua regia at $250{ }^{\circ} \mathrm{C}$ in a microprocessor-controlled digestion box for $2 \mathrm{~h}$.

Analytical technique

Both the soils and water samples were analyzed for the following trace elements: $\mathrm{Cr}, \mathrm{Ni}, \mathrm{Co}, \mathrm{As}, \mathrm{Se}, \mathrm{Pb}, \mathrm{Cu}, \mathrm{V}, \mathrm{Be}$, $\mathrm{Cd}, \mathrm{Ni}, \mathrm{Sb}$, and $\mathrm{Zn}$ by inductively coupled plasma-mass spectroscopy (ICP/MS) using a Perkin Elmer SCIEX ELAN 6100. The quality of the analysis was controlled through the analysis of International certified reference materials USGS GXR-1, GXR-2, GXR-4, and GXR-6 introduced at the beginning and end of each batch of samples. Internal control standards are analyzed every 10 samples and a duplicate is run for every 10 samples. The values obtained by the instrument from the reagent blank are automatically subtracted from the raw data before printout. This makes the data free from whatever impurities inherited from the reagents including distilled and de-ionized water. The results turnouts have an accuracy of $\pm 2-5 \%$ depending on the number of standards used and concentration levels. The instrument was calibrated prior to the introduction of sample by measuring in-house standards and blank solutions. Ion chromatography was used to analyze for Fluoride including other anions such as $\mathrm{Cl}, \mathrm{Br}$, $\mathrm{NO}_{2}, \mathrm{NO}_{3}, \mathrm{PO}_{4}$ and $\mathrm{SO}_{4}$.

Data evaluation

\section{Determination of enrichment factor $(E F)$}

To assess the level of depletion or enrichment of the heavy elements in the soils, an enrichment factor was used (Krzysztof et al. 2003), where;

$\mathrm{EF}=\frac{C_{n}(\text { sample }) / C_{\text {ref }}(\text { sample })}{B_{n}(\text { background }) / B_{\text {ref }}(\text { background })}$

where $C_{n}$ (sample) $=$ concentration of the elements in the soil sample, $C_{\text {ref }}$ (sample) $=$ concentration of the element in the fresh basalt, $B_{n}$ (background) = mean of the concentration of the elements in the soil sample, and $B_{\text {ref }}$ (background) $=$ mean of the concentration of the elements in the fresh basalt.

The EF values are classified into five (5) classes by Sutherland (2000), where $0 \geq \mathrm{EF} \leq 2$ is classed as deficiently to minimal enrichment (Class 1); EF between 2 and 5 signifies moderate enrichment (Class 2); $5 \geq \mathrm{EF} \leq 20$ indicates significant enrichment (Class 3); values of $20 \geq \mathrm{EF} \leq 40$ are classified as very high enrichment 
Table 1 The values of the enrichment factor of the PHEs in the volcanic soils

\begin{tabular}{lllllllllllll}
\hline Locations & $\mathrm{As}$ & $\mathrm{Be}$ & $\mathrm{Cd}$ & $\mathrm{Co}$ & $\mathrm{Cr}$ & $\mathrm{Cu}$ & $\mathrm{Ni}$ & $\mathrm{Pb}$ & $\mathrm{Sb}$ & $\mathrm{Se}$ & $\mathrm{V}$ & $\mathrm{Zn}$ \\
\hline Ajing1 & 0.01 & 2.99 & 0.30 & 2.40 & 2.18 & 2.77 & 5.46 & 0.78 & 0.41 & 0.18 & 1.97 & 1.30 \\
Bwonpe & 0.01 & 2.99 & 0.20 & 2.78 & 2.78 & 2.95 & 7.40 & 0.55 & 0.31 & 0.12 & 2.30 & 1.35 \\
Kurgwam & 0.01 & 2.87 & 0.35 & 2.42 & 2.42 & 2.61 & 6.00 & 0.44 & 0.10 & 0.15 & 2.00 & 1.35 \\
Punguk & 0.01 & 3.35 & 0.25 & 2.52 & 1.64 & 0.60 & 3.96 & 0.69 & 0.31 & 0.12 & 1.95 & 1.29 \\
Amshal & 0.01 & 2.99 & 0.30 & 1.76 & 1.37 & 1.53 & 2.47 & 0.82 & 0.31 & 0.15 & 2.33 & 1.00 \\
Konji & 0.01 & 2.40 & 0.40 & 1.67 & 1.29 & 1.65 & 1.61 & 1.02 & 0.26 & 0.06 & 1.86 & 0.86 \\
Ugut & 0.01 & 2.40 & 0.40 & 1.67 & 1.29 & 1.89 & 2.27 & 0.70 & 0.41 & 0.12 & 1.59 & 1.60 \\
\hline
\end{tabular}

(Class 4) and finally EF $\geq 40$ is characterized as extremely high enrichment (Class 5). EF values equal to or less than 1 indicate no anthropogenic contribution but from predominantly crustal material (the background) and/or weathering process, whereas EF values greater than 1 suggest an anthropogenic origin of the element (Gong et al. 2008). The values of the enrichment factors for each of these elements are presented in Table 1.

\section{Determination of pollution load index (PLI)}

To assess the extent to which the volcanic soil have been contaminated by the PHEs, a pollution load index (PLI) (Tomlinson et al. 1980) was employed and is expressed by the equation:

\section{$\mathrm{PLI}=\sqrt{\mathrm{CF} 1 \times \mathrm{CF} 2 \times \mathrm{CF} 3 \times \ldots \ldots \mathrm{CFN}}$}

where $\mathrm{CF}$, contamination factor $=C_{\text {metal }} / C_{\text {background value, }}$ $N$, number of heavy metals, $C_{\text {metal, }}$ the concentration of pollutant in soils, $C_{\text {background, }}$, background value of the heavy metal. The values of PLI are presented in Table 2 . The PLI values are classified into 5 classes ranging from uncontaminated (PLI value of $<1$ ) to extremely contaminated (PLI value of $>1$ ). The contamination factor $(\mathrm{CF})$ has been categorized ranging from low contamination to very high contamination as shown below (Hakanson 1980):

\begin{tabular}{ll}
\hline Contamination factor & Level of contamination \\
\hline $\mathrm{CF}<1$ & Low contamination \\
$1 \leq \mathrm{CF}<3$ & Moderate contamination \\
$3 \geq \mathrm{CF}<6$ & Considerable contamination \\
$\mathrm{CF}>6$ & Very high contamination \\
\hline
\end{tabular}

Calculation of the percent change in the concentration of the total rare earth elements (REE)

A simple mass balance calculation is used here to determine the percentage change in the concentration of the
REEs in the basaltic rocks during alteration. The percentage increase or decrease of the REEs in a sample relative to the reference fresh parent basaltic rock is calculated using the formula $\left(\left(\sum \text { REEs }\right)_{\text {sample }} /\left(\sum \text { REEs }\right)_{\text {parentrock }}\right)$ $1 \times 100 \%$ (Lar et al. 2000, modified from Nesbitt 1979). The values for the percentage change in the REEs in the samples are presented in Table 3 . The percentage change of the REEs in a sample relative to that of the reference parent rock approaches $100 \%$ whenever the sample is severely weathered and is equal to $0 \%$ for unaltered rocks.

\section{Results and discussion}

The potentially harmful elements (PHEs) and rare earth elements (REEs) compositions in the volcanic soils are presented in Tables 3 and 4, respectively.

Table 2 Pollution load index of potential harmful elements (PHE) in volcanic soils of the study area

\begin{tabular}{lll}
\hline Metal & Pollution load index & Remark \\
\hline $\mathrm{As}$ & 00 & Uncontaminated \\
$\mathrm{Be}$ & $0.50-0.90$ & Uncontaminated \\
$\mathrm{Cd}$ & -2.00 to -3.00 & Uncontaminated \\
$\mathrm{Co}$ & -0.20 to -0.89 & Uncontaminated \\
$\mathrm{Cr}$ & -0.2 to 0.40 & Uncontaminated \\
$\mathrm{Cu}$ & -1.3 to -3.70 & Uncontaminated \\
$\mathrm{Ni}$ & -1.10 to 1.10 & Uncontaminated to \\
& & moderately contaminated \\
$\mathrm{Pb}$ & $0-0.80$ & Uncontaminated \\
$\mathrm{Sb}$ & -2.1 to -3.90 & Uncontaminated \\
$\mathrm{Se}$ & $1.40-3.00$ & Moderately contaminated \\
& -1.20 to -1.80 & Uncontaminated \\
$\mathrm{V}$ & -0.5 to -1.3 & Uncontaminated \\
$\mathrm{Zn}$ &
\end{tabular}




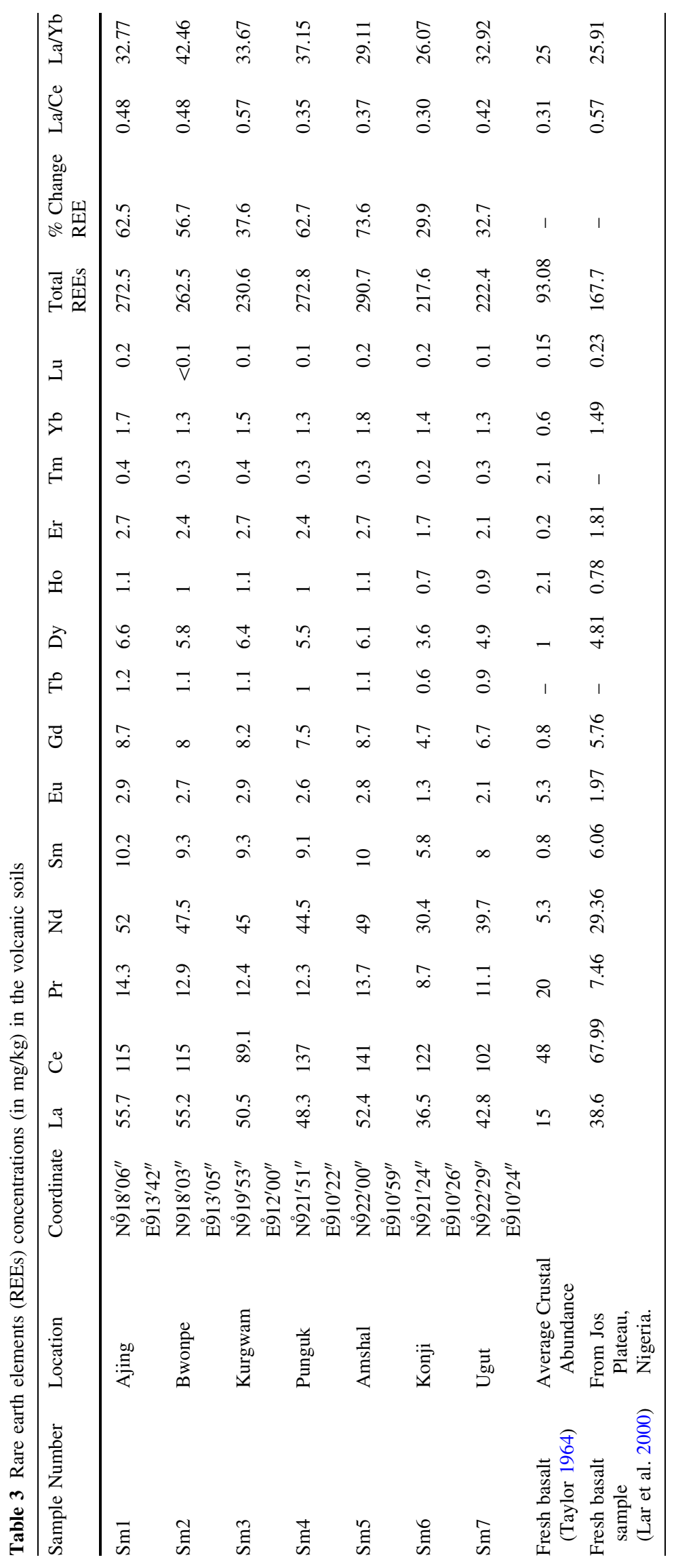




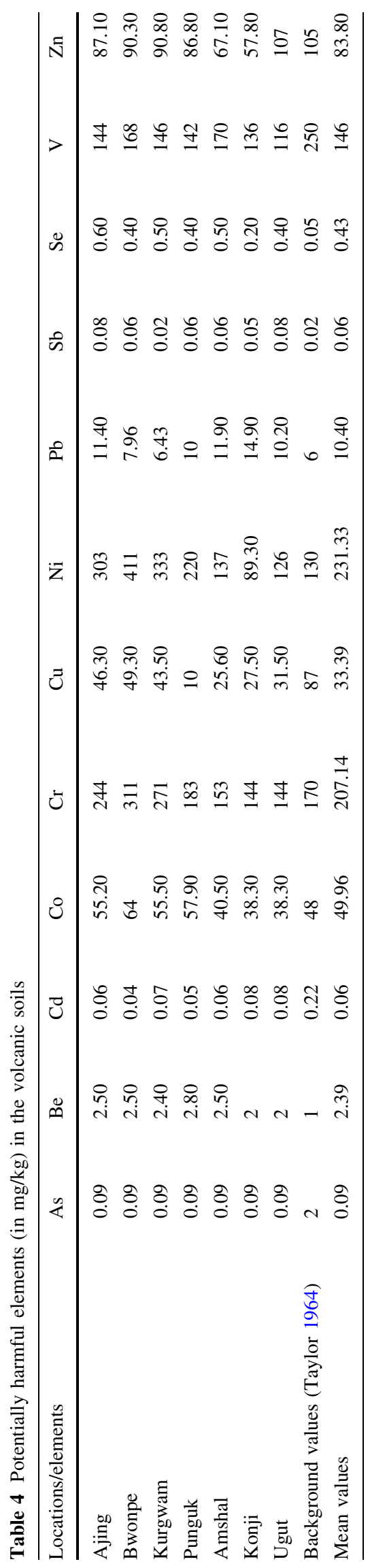

Major cations and anions in the water sources

Analysis of the major dissolved cations and anions in the underground water sources (springs/boreholes) is presented in Table 5.

Magnesium concentration in the waters vary between 2.2 and $26.4 \mathrm{mg} / \mathrm{l}$ (mean of $18 \mathrm{mg} / \mathrm{l}$ ) and calcium varies between 4.7 and $27.6 \mathrm{mg} / \mathrm{l}(\mathrm{mean}=15 \mathrm{mg} / \mathrm{l})$. Both $\mathrm{Mg}$ and $\mathrm{Ca}$ display values below the maximum permissible limits of 50 and $75 \mathrm{mg} / \mathrm{l}$, respectively. Sodium and potassium display concentrations varying from 8-61.3 (mean $14 \mathrm{mg} / \mathrm{l})$ to $2.1-18.8 \mathrm{mg} / \mathrm{l}($ mean $8 \mathrm{mg} / \mathrm{l})$, respectively. The cation levels decrease in the order $\mathrm{Mg}>\mathrm{Ca}>\mathrm{Na}>\mathrm{K}$ (Table 5). The bicarbonate concentration varies between 78.66 and $461.61 \mathrm{mg} / \mathrm{l}$ (mean $=310 \mathrm{mg} / \mathrm{l}$ ). The chloride concentration remains relatively constant in all the waters with a mean of $6 \mathrm{mg} / \mathrm{l} . \mathrm{HCO}_{3}$ is the dominant anion (mean values $309.75 \mathrm{mg} / \mathrm{l}$ ) followed in decreasing order by $\mathrm{SO}_{4}>\mathrm{Cl}>\mathrm{NO}_{3}$. None of these cations exhibits values that exceed the WHO (2004) permissible limits in drinking water (Table 5), suggesting a low level of anthropogenic input, which is further corroborating the minimal pollution loadings into the entire volcanic province as revealed in the calculated PLI values below.

In an attempt to classify these underground waters and to better understand the hydrogeochemical processes controlling water chemistry, the major ions are plotted in a piper diagram as cation and anion percentages in milliequivalent (meq) (Fig. 17). In the Piper diagram, most of the water samples fall in the top central portion of the cation triangle indicating the dominance of the alkali earth metals $\left(\mathrm{Mg}^{2+}+\mathrm{Ca}^{2+}\right)$ over the alkali metals $\left(\mathrm{Na}^{+}+\mathrm{K}^{+}\right)$, suggesting a mixing of $\mathrm{Mg}-\mathrm{Ca}-\mathrm{HCO}_{3}$ and $\mathrm{Na}-\mathrm{K}-\mathrm{HCO}_{3}$ water types. The presence of these two water types is a reflection of the interaction between the predominant granitic basement rocks and the basaltic cover in the study area. The water samples that plot close to the $\mathrm{Na}^{+}$and $\mathrm{K}^{+}$ field seem to have originated from a volcanic aquifer derived from the dissolution of plagioclase in the basaltic rocks.

A correlation between fluoride content in water and other ions are also presented to best understand the behavior of $\mathrm{F}$ in the classified water chemical types. The concentration of Fluoride is positively correlated with $\mathrm{Mg}^{2+}, \mathrm{Ca}^{2+}, \mathrm{Na}^{+}$(Figs. 12, 13, 14) as well as with $\mathrm{K}^{+}$ (Fig. 15) and $\mathrm{Ba}^{2+}$ (Fig. 16), indicating that these cations are of similar source and or controlled by the same geochemical process. The $\mathrm{NO}_{3}{ }^{2-}$ content does not seem to affect the $\mathrm{F}^{-}$content (Fig. 11), indicating an external source for the $\mathrm{NO}_{3}{ }^{2-}$.

The significantly low F content below the WHO admissible limit of $1.5 \mathrm{mg} / \mathrm{l}$ for drinking water (World Health Organization 2004) in both the spring and borehole waters 
Table 5 Major cations and anions in the waters $(\mathrm{mg} / \mathrm{l})$ of the Panyam Volcanic province

\begin{tabular}{llcccccccccc}
\hline Element & Water source & $\mathrm{K}^{+}$ & $\mathrm{Na}^{+}$ & $\mathrm{Mg}^{2+}$ & $\mathrm{Ca}^{2+}$ & $\mathrm{HCO}_{3}^{-}$ & $\mathrm{SO}_{4}^{2-}$ & $\mathrm{Cl}^{-}$ & $\mathrm{NO}_{3}^{2-}$ & $\mathrm{F}^{-}$ & $\mathrm{Ba}^{2+}$ \\
\hline Ajing1 & Borehole & 4.3 & 9.9 & 19.7 & 14.5 & 250.47 & 1.33 & 7.63 & 4.32 & 0.12 & $<0.02$ \\
Bwonpe & Spring & 5.5 & 11.9 & 17.5 & 14.2 & 264.96 & 5.33 & 5.1 & 1.13 & 0.19 & $<0.02$ \\
Kurgwam & Borehole & 2.5 & 9 & 2.2 & 4.7 & 78.66 & $<0.03$ & 2.28 & 1.17 & 0.12 & 0.02 \\
Panyam & Borehole & 6.1 & 61.3 & 16.2 & 16.3 & 459.54 & 55.1 & 7.27 & $<0.02$ & 0.59 & 0.04 \\
T/Kerang & Spring & 9.1 & 19.7 & 22.6 & 27.6 & 418.14 & 4.36 & 9.24 & 2.79 & 0.14 & 0.04 \\
Punguk & Spring & 5.9 & 13.4 & 18.3 & 22 & 333.27 & 3.38 & 4.88 & 2.52 & 0.20 & 0.03 \\
Kerang & Spring & 2.1 & 8 & 13.7 & 14.3 & 311.14 & 2.09 & 6.84 & 0.86 & 0.15 & 0.05 \\
Amshal 1 & Spring & 8.1 & 12.9 & 18.2 & 14.9 & 279.45 & 3.05 & 3.88 & 3.19 & 0.21 & $<0.02$ \\
Amshal 2 & Spring & 7.1 & 11.5 & 16.2 & 14.5 & 225.63 & 3.35 & 4.79 & 4 & 0.18 & $<0.02$ \\
Konji & Spring & 7.6 & 10.9 & 15.4 & 17.9 & 262.89 & 3.58 & 4.27 & 2.23 & 0.20 & 0.06 \\
Jwakmang & Borehole & 18.8 & 28.2 & 26.4 & 24.6 & 461.61 & 1.86 & 8.58 & 2.12 & 0.18 & $<0.02$ \\
Ugut & Spring & 8.6 & 23.2 & 20.5 & 21.5 & 382.95 & 7 & 6.18 & 1.44 & $\mathrm{Nil}$ & $<0.02$ \\
Pang & Spring & 9 & 15.2 & 21.5 & 15.8 & 298 & 2.95 & 5.52 & 4.5 & $\mathrm{Nil}$ & $<0.02$ \\
WHO (2004) & & 200 & 200 & $50-150$ & $75-200$ & $\mathrm{NS}$ & 250 & 250 & 50 & 1.50 & 0.70 \\
\hline
\end{tabular}

of the volcanic province is in support of its origin from shallow aquifers often recharged by precipitation with little resident time for ion exchange and accumulation. The spring water in the volcanic province is the main source of potable drinking water for the inhabitants. The observed tooth decay (Plate 2) and dental caries which are a common dental disease conditions among the elderly people (30 years and above) in the province is a reflection of this low fluoride level in the waters. These disease conditions are however absent in the younger children in the volcanic province, who have resorted to the use of fluoride toothpaste in recent times.

Potentially harmful elements (PHEs) (As, Be, Cd, Co, $\mathrm{Cr} \mathrm{Cu}, \mathrm{Ni}, \mathrm{Pb}, \mathrm{Sb}, \mathrm{Se}, \mathrm{V}$ and $\mathrm{Zn}$ ) in the volcanic soil

The concentration levels of PHEs in the volcanic soils are presented in Table 4. The values for the EF of each of these elements are also presented in Table 2.

Except for $\mathrm{Ni}$ and $\mathrm{Se}$, most of these elements display values that below the regional baseline values and are concentrated in lateritic soils. As, $\mathrm{Be}, \mathrm{Cd}, \mathrm{Co}, \mathrm{Cr}, \mathrm{Cu}, \mathrm{Ni}$, $\mathrm{Pb}, \mathrm{Sb}, \mathrm{V}$ and $\mathrm{Zn}$ display average concentrations of 0.09 , 2.39, 0.06, 49.96, 207.14, 33.39, 231.33, 10.40, 0.06, 146 and $83.84 \mathrm{mg} / \mathrm{kg}$, respectively.

Beryllium presents moderate enrichment $(2 \leq \mathrm{EF} \leq 5)$ in about $3 / 4$ of the volcanic province (Fig. 3) and minimal enrichment $(\mathrm{EF} \leq 2)$ outside this zone. Also, $\mathrm{Co}, \mathrm{Cr}$ and $\mathrm{Cu}$ display moderate enrichment $(2 \leq \mathrm{EF} \leq 5)$ in the southeast portion of the volcanic province especially in areas around Ajing, Bwonpe, Kurgwam (Figs. 4, 5, 6). Vanadium on the

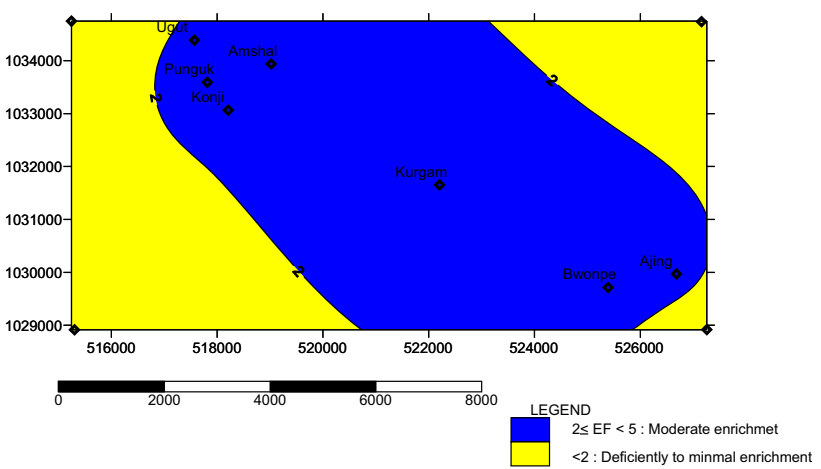

Fig. 3 Enrichment factor map for Beryllium

other hand exhibits a rather "swell and pinch" enrichment pattern running diagonally from NW to SE covering the villages of Pungul, Amshal in the NW to Kurgum and to Bwonpe and Ajing in the SE. Nickel, however, displays strong to severe enrichment $(5 \leq \mathrm{EF} \leq 20)$ (Fig. 7) in the SE portion of the volcanic province, with values decreasing outwards to moderate enrichment $(2 \leq \mathrm{EF} \leq 5)$ towards Punguk, Amshal and Konji followed by a minimal enrichment outside these areas (Fig. 8). Other elements such as $\mathrm{As}, \mathrm{Cd}, \mathrm{Pb}, \mathrm{Sb}, \mathrm{Se}$ and $\mathrm{Zn}$ display minimal enrichment in some other areas in the volcanic soils $(0 \leq \mathrm{EF} \leq 2)$. These PHEs ( $\mathrm{Co}, \mathrm{Cr}, \mathrm{Cu}, \mathrm{Ni}, \mathrm{V}$ and $\mathrm{Zn}$ ) are often associated with $\mathrm{Fe}$ and therefore are preferentially scavenged or co-precipitated along with Fe-rich mineral phases in the lateritized volcanic soils (Zhang et al. 2007).

Except for $\mathrm{Ni}$ and $\mathrm{Se}$ which present pollution indices (PLI) of 1.10 and 1.40-3.0, respectively, suggesting a moderate contamination for $\mathrm{Ni}$ and from moderate to 


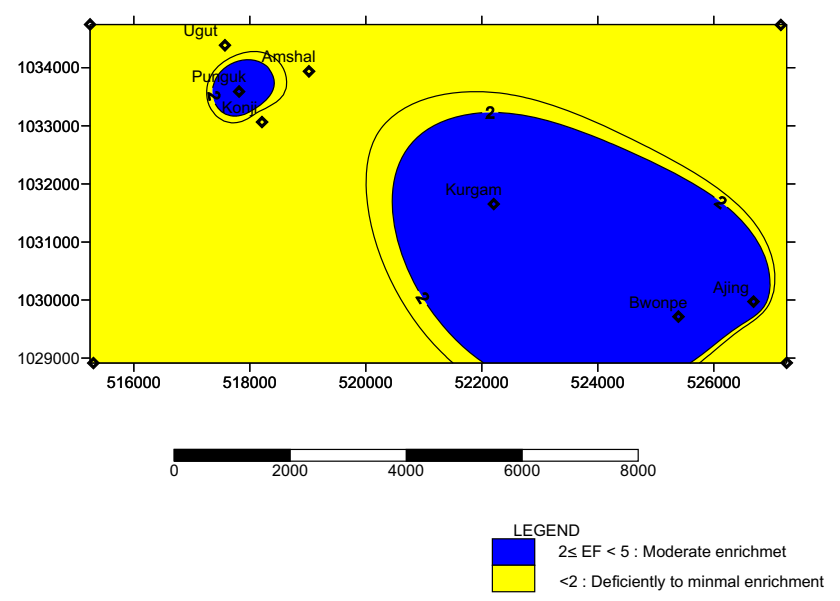

Fig. 4 Enrichment factor map for Cobalt

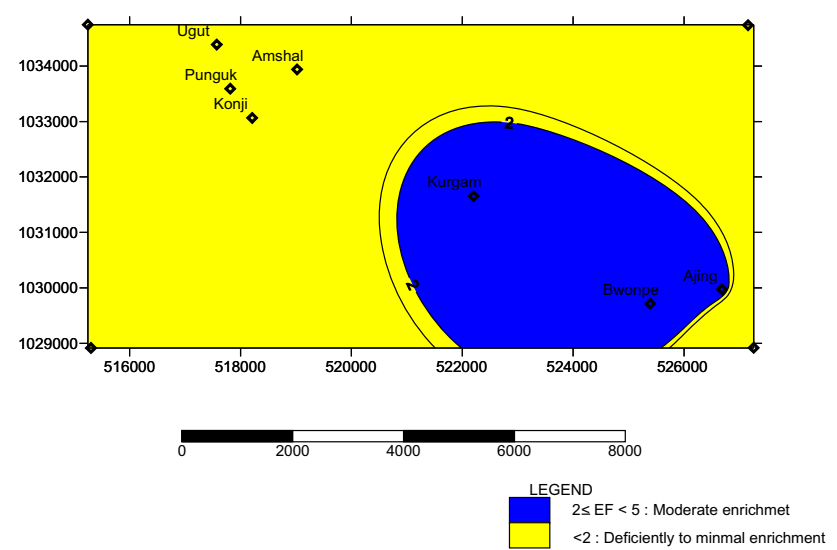

Fig. 5 Enrichment factor map for chromium

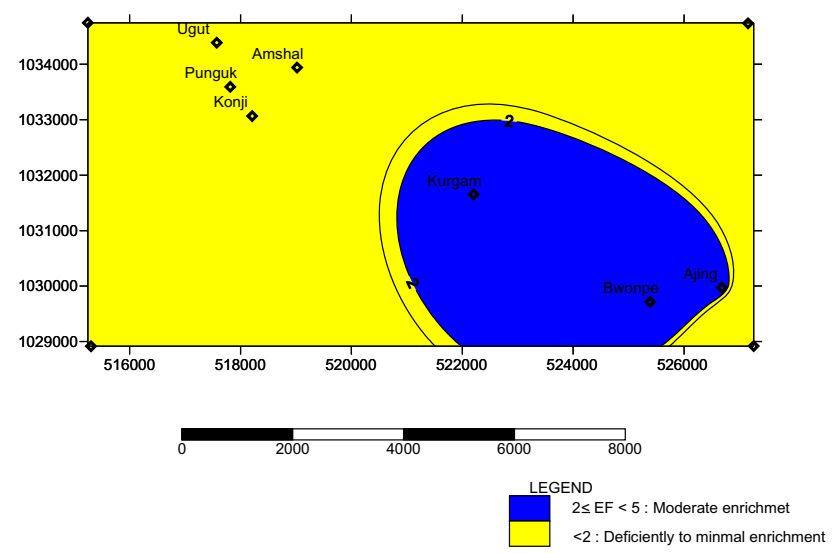

Fig. 6 Enrichment factor map for Copper

strong contamination for Se, all the other elements As, $\mathrm{Be}, \mathrm{Pb}, \mathrm{Cd}, \mathrm{Cr}, \mathrm{Cu}, \mathrm{Sb}, \mathrm{V}$ and $\mathrm{Zn}$ present $\mathrm{PLI}<1$, and therefore did not contaminate the soil (Table 2). Pre-

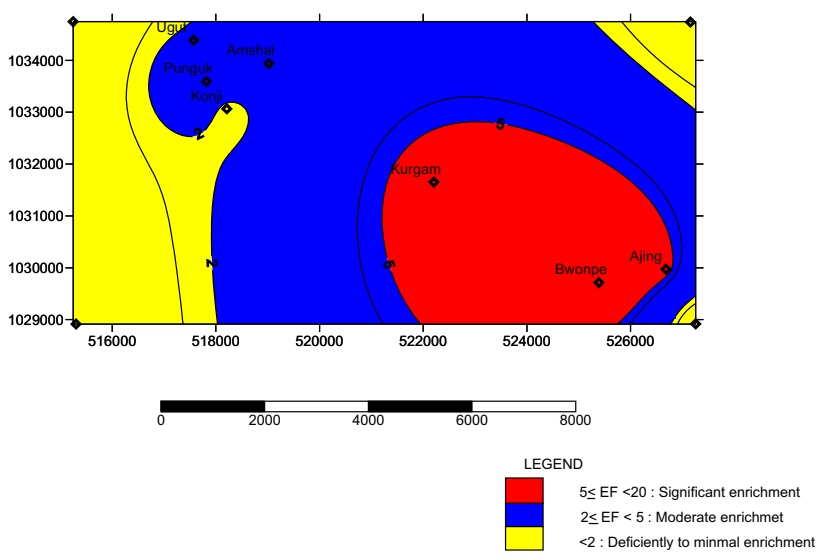

Fig. 7 Enrichment factor map for Nickel

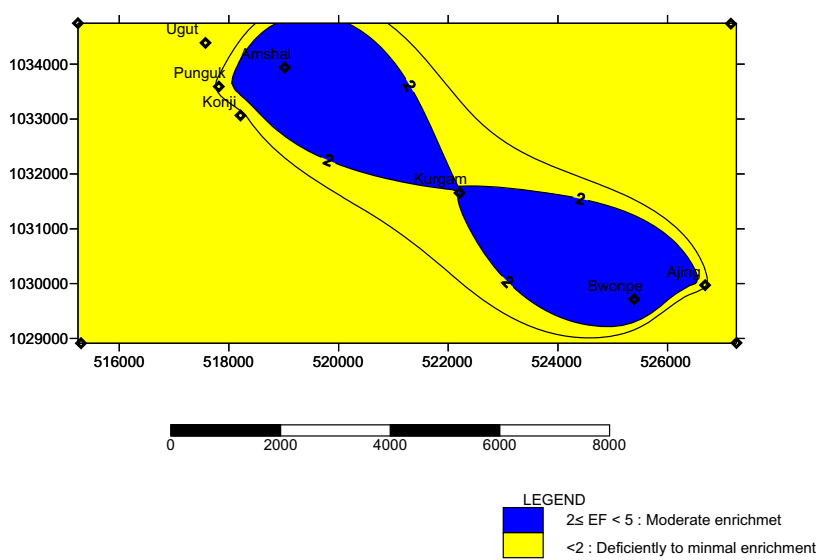

Fig. 8 Enrichment factor map for Vanadium

sumably, the endemic non-filarial elephantiasis observed affecting some inhabitants of the volcanic province might have been caused by the exposure of the unprotected feet to $\mathrm{Be}$ and $\mathrm{Zr}$, in volcanic soils, known to induce the development of podoconiosis (Frommel et al. 1993; Davey et al. 2007; Price 1974), (Plate 1).

Rare earth elements (REEs)

The values of the sum total of REEs ( $\sum$ REEs) for each sample are presented in Table 3 and range from 217.6-290.7 relative to $167.7 \mathrm{mg} / \mathrm{kg}$ for the parent basaltic rock material.

The REEs composition of the volcanic soils and the reference parent basaltic rock normalized to chondrites plotted in a spidergragh (Figs. 9, 10) display clear light rare earth elements (LREE) $(100-200 \times$ Chondrite) enrichment relative to heavy rare earth elements (HREE) $(2-5 \times$ Chondrite) typical of the continental basalts (Fig. 9). There 


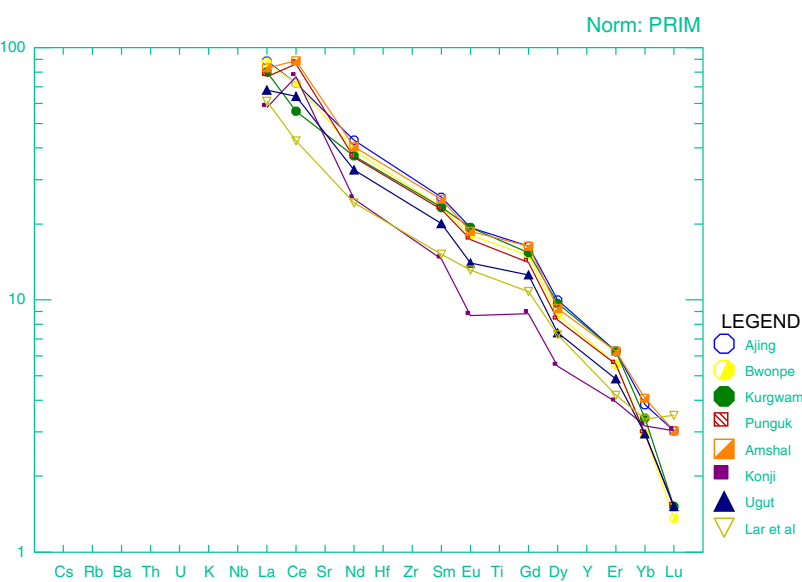

Fig. 9 Spidergraph of rare earth elements in the volcanic soils compared with parent basalt rock material from the Jos Plateau (in Lar et al. 2000)

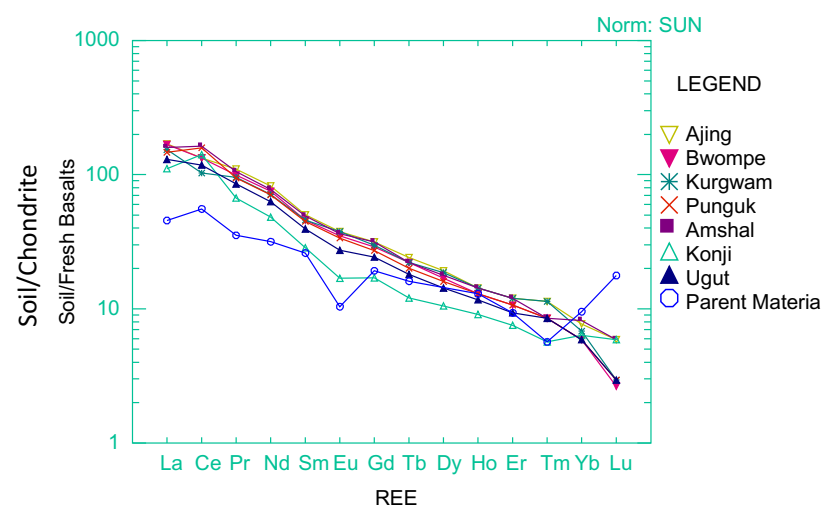

Fig. 10 Spidergraph of rare earth elements in the volcanic soils compared with the chondrite

is a similarity in the spectra of the volcanic soils with that of the reference parent basaltic rock indicating a derivation from the same parent material and/or have been affected by the same process with the same intensity (Lar and Tsalha 2005).

The volcanic soils normalized to the reference parent rock, however, also display LREEs enrichment up to $70-80 \times$ relative to HREE of $1-4 \times$.

The percentage change in the concentrations of the total REEs in the soils, which could possibly be explained by alteration processes show that the accumulation of REEs ranges from 32.7 to $73.6 \%$ (Table 3). Only Sample SM5 shows significant REE enrichment of up to $73.6 \%$ relative to that of the parent rock. For example, in the case of

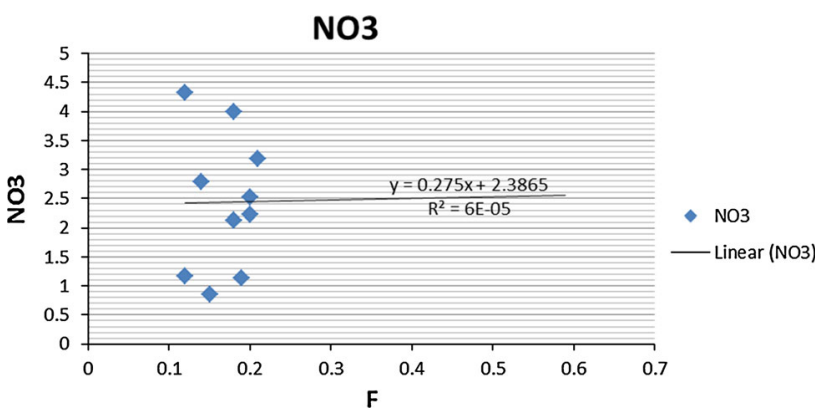

Fig. 11 Correlation diagram of $\mathrm{NO}_{3}{ }^{2-}$ versus $\mathrm{F}^{-}$in waters from the Volcanic province

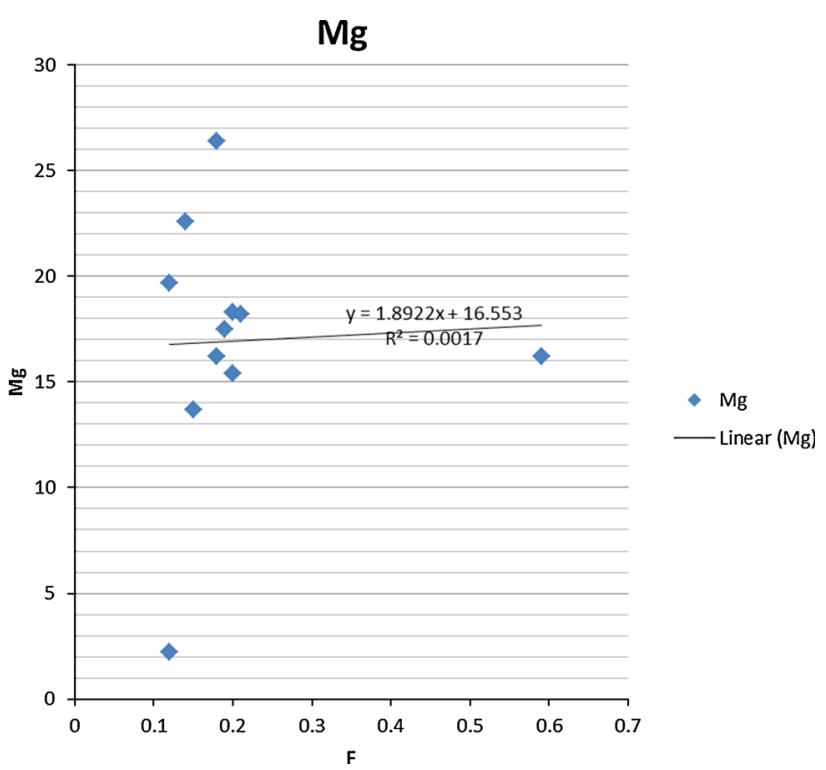

Fig. 12 Correlation diagram of $\mathrm{Mg}^{2+}$ versus $\mathrm{F}^{-}$in waters from the Volcanic province

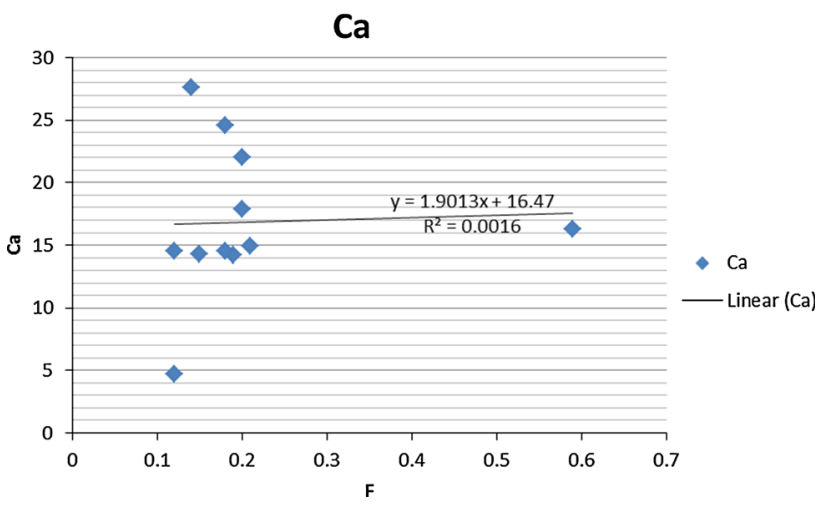

Fig. 13 Correlation diagram of $\mathrm{Ca}^{2+}$ versus $\mathrm{F}^{-}$in waters from the Volcanic province 


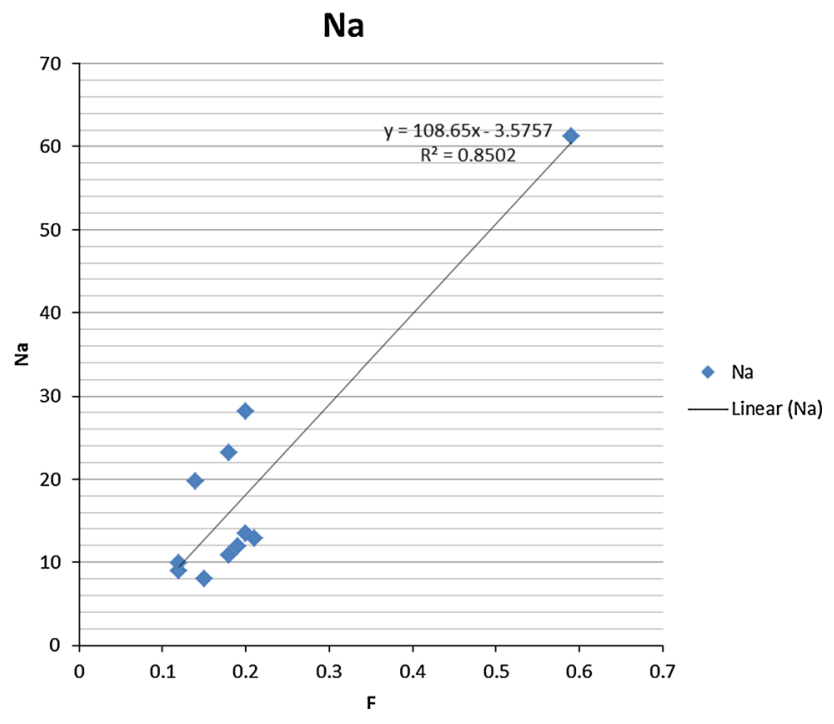

Fig. 14 Correlation diagram of $\mathrm{Na}^{+}$versus $\mathrm{F}^{-}$in waters from the Volcanic province

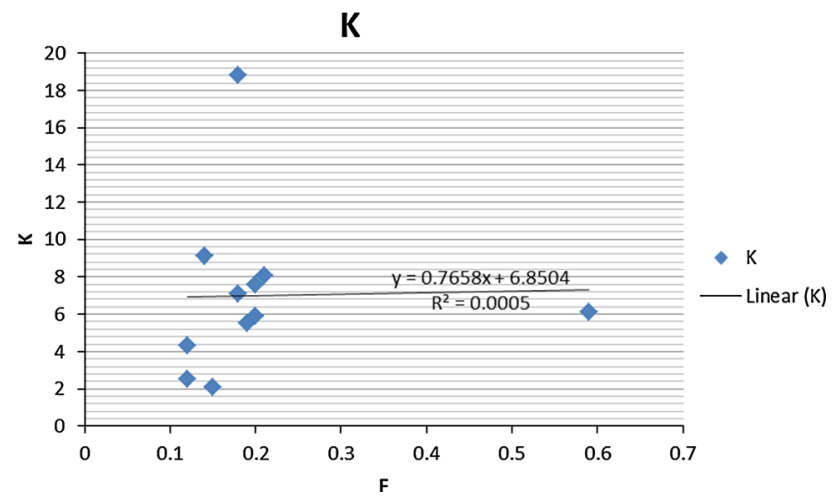

Fig. 15 Correlation diagram of $\mathrm{K}^{+}$versus $\mathrm{F}^{-}$in waters from the Volcanic province

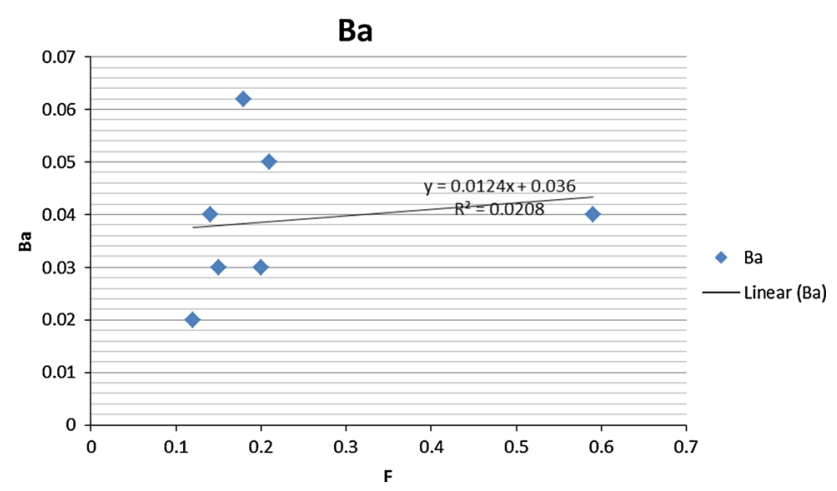

Fig. 16 Correlation diagram of $\mathrm{Ba}^{2+}$ versus $\mathrm{F}^{-}$in waters from the Volcanic province samples SM1, 2 and 4, about 56-62\% of the REEs was accumulated, while for samples 3,6 and 7, they display moderate enrichment in the range $30-38 \%$. These values are well corroborated with the $\mathrm{La} / \mathrm{Ce}$ ratios ranging from $0.30-0.37$ to $0.42-0.57$ relative to 0.57 in the reference parent rock suggesting that the degree of weathering on the parent basaltic rocks was mainly moderate but severe in some cases. Indeed, the visible positive $\mathrm{Ce}$ anomalies in all the soil samples go further to support the high degree of weathering the parent basaltic rocks of the volcanic province must have undergone (Figs. 11, 12, 13, 14, $15,16,17)$

The calculated $73.6 \%$ accumulation in sample SM5 (Table 3), implies the severity of weathering in places. However, its low $\mathrm{La} / \mathrm{Ce}$ ratio $(0.35)$ with a very high percentage of total REEs, instead of a lower total REEs, can best be explained by significant enrichment of total HREE relative to total LREE values in this case, and this can be supported to by the decreasing $\mathrm{La} / \mathrm{Yb}$ ratios from $42.46>37.15>33.67>32.77>29.11 \quad$ and $>26.7$

(Table 3).

\section{Conclusion}

This study has established that the dominant underground water types in the volcanic province is the $\mathrm{Mg}-\mathrm{Ca}-$ $\mathrm{HCO}_{3}$ water type forming $80 \%$ and $\mathrm{Na}-\mathrm{K}-\mathrm{HCO}_{3}$ water type making the remaining $20 \%$. The composition of these major ions in the waters seems to have been controlled by the water-rock alteration process(es) by mixing of water from the dominant underlying host crustal and the overlying basaltic rocks in the volcanic province.

It has also revealed that the soils in the Panyam volcanic province are minimally to moderately enriched in most potentially harmful elements $(\mathrm{Be}, \mathrm{Co}, \mathrm{Cr}, \mathrm{Ni}, \mathrm{Pb}$, $\mathrm{Sb}, \mathrm{Se}, \mathrm{V}$ and $\mathrm{Zn}$ ), with $\mathrm{Ni}$ and Se displaying strong enrichments. The higher baseline values of these transition metals are due to their relative immobility as they substitute and co-precipitate along with $\mathrm{Fe}$ during the weathering of the basalt host rocks. Except for $\mathrm{Ni}$ and $\mathrm{Se}$ which seem to have contaminated the volcanic soils, these other elements $\mathrm{As}, \mathrm{Be}, \mathrm{Cd}, \mathrm{Cr}, \mathrm{Cu}, \mathrm{Pb}, \mathrm{Sb}, \mathrm{V}$ and $\mathrm{Zn}$ did not, suggesting little or no anthropogenic input. The rare earth elements are equally significantly enriched in the volcanic soils as a result of moderate to slightly severe intensity of weathering the parent basaltic rocks were subjected to. 
Fig. 17 Piper Trilinear diagram of waters from the volcanic province
Piper trilinear diagram of volcanic aquifers of the study area

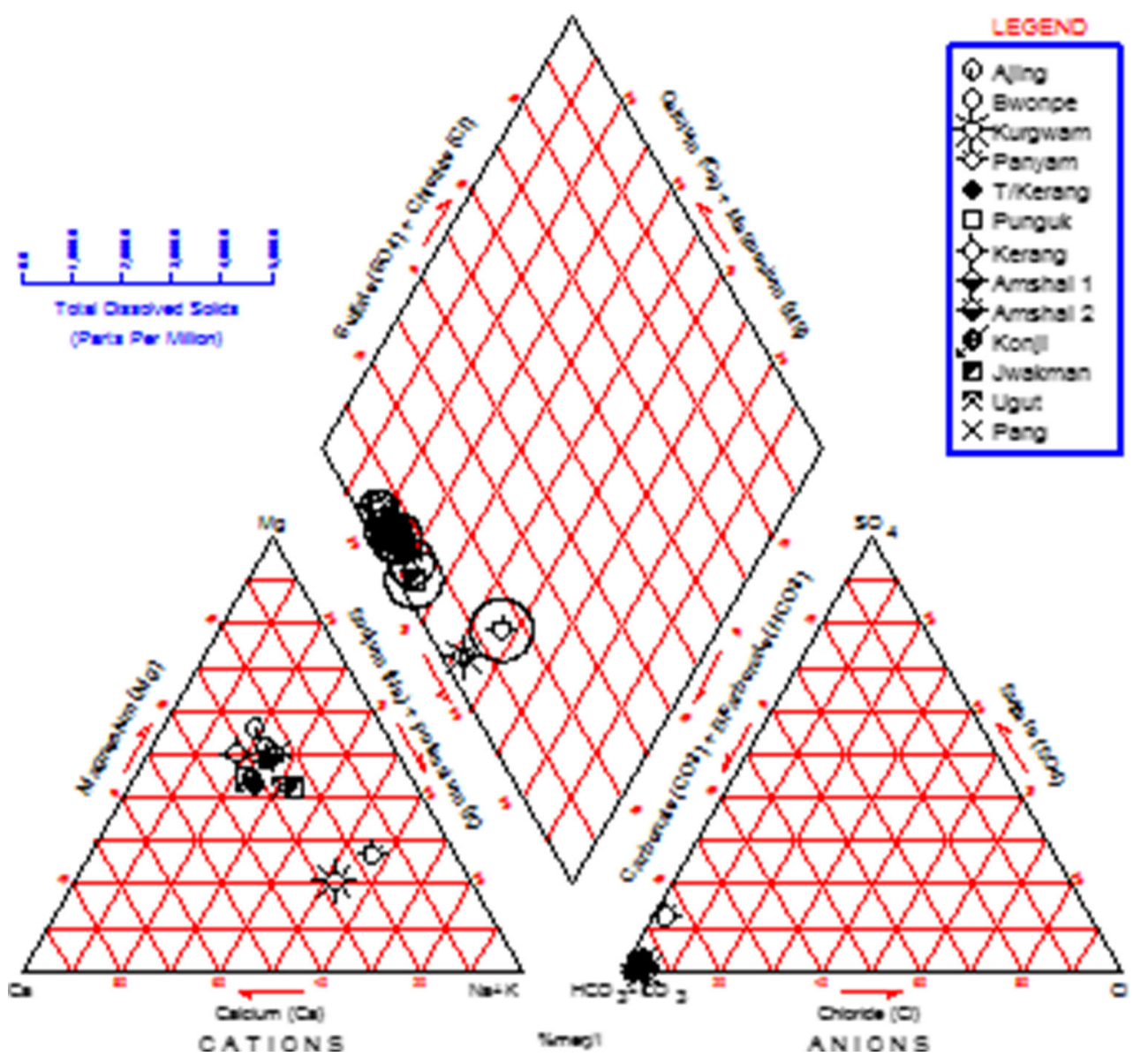

The common human disease conditions observed in the volcanic province, podoconiosis and tooth decay/dental caries are a reflection of the higher contents of the heavy metals and the deficiency of fluoride in waters, respectively. We advocate for a more comprehensive research to establish the links between the distribution of these potentially harmful elements in the volcanic soils and the many observed common human disease conditions.

Acknowledgments This paper is part of an ongoing research on leaching from basaltic volcanic rocks into the surrounding ecosystems in Nigeria. We thank the anonymous reviewers for their encouragement by their constructive criticisms which have immensely improved on the quality of the paper.

Open Access This article is distributed under the terms of the Creative Commons Attribution License which permits any use, distribution, and reproduction in any medium, provided the original author(s) and the source are credited.

\section{References}

Cicchella D, De Vivo B, Lima A (2005) Background and baseline concentration values of elements harmful to human heath in the volcanic soils of metropolitan and provincial areas of Napoli (Italy): geochemistry Exploration. Enivron Anal 5:29-40

Cortizas AM, Gayoso GR, Munoz JCN, Pombal PB, Terribile F (2003) Distribution of some selected major and trace elements in four Italian soils developed from deposits of Gauro and Vico volcanoes. Sci Dorect 117:215-225

Darnley AG, Bjorklund A, Bolviken B, Gustavsson N, Koval PV, Plant JA, Steenfelt A, Tauchid M, Xie X (1995) A global geochemical database for environmental and resource management: Recommendations for International Geochemical Mapping. Final Report of IGCP Project 256. Earth Sciences 19, UNESCO

Davey G, Tekola F, Newport-Melaine J (2007) Podoconiosis: noninfectious geochemical elephantiasis. Trans R Soc Trop Med Hyg 101(12):1175-1180

Davies TC (1995) The geochemical behavior of iodine in natural waters of the Kianbu and Eldoret areas of Kenya: (IO Nyanbok, Ed), Geology for Development within a sustainable Environment, 637-640

Davies TC (2008) Environmental health impact of East African Rift volcanism. Environ Geochem Health 30:325-338

Fratinin P, Devivu B, Lima A, Cicchella D (2006) Elemental and gamma-ray survey in volcanic soils of Ischia Island, Italy. Assoc Appl Geochem Geol Soc 6(4):325-339

Frommel D, Ayranci B, Pfeifer HR, Sanchez A, Frommel A, Mengistis G (1993) Podoconiosis in the Ethiopian Rift vally: role of beryllium and zirconium. Trop Geogr Med 45(4):165-167 
Gong Q, Deng J, Xiang Y, Wang Q, Yang L (2008) Calculating pollution indices by heavy metals in ecological geochemistry assessment and a case study in parks of Beijing. J China Univ Geosci 19(3):230-241

Gusikit RB (2010) Major and trace elements distribution in natural and soils in Panyam Volcanic Province. Unpublished M.Sc. dissertation, University of Jos, Nigeria, pp 58-128

Hakanson L (1980) An ecological risk index for aquatic pollution control and sedimentological approaches. Water Res 14:975-1001

Krzysztof L, Wiechula D, Korns I (2003) Metal contamination of farming soils affected by industry. Environ Int 30:159-165

Lar UA, Tsalha M (2005) Geochemical characteristics of the Jos Plateau Basalts, north central Nigeria. Glob J Geol Sci 2:187-193

Lar UA, Usman AM (2012) Environmental distribution of trace metals in the Biu Volcanic Province Nigeria: exposure and associated human health problems. Int J Sci Eng Res 3:1-14

Lar UA, Walsh N, Ashano EC, Ogezi AE, Nixon PH (2000) Mobilization Major, minor, and trace elements including the REEs In weathered basaltic materials of the Jos Plateau, Nigeria. Afr J Nat Sci 3:40-56

Lar UA, Anifowoshe AYB, Mahmud UM, Shaibu MT, Akpan OU, Tsebeje ST (2007) Report on the Geohazard mapping of volcanoes in Nigeria. Commissioned by the Centre for Geodesy and Geodynamics, Toro, NARSDA, Federal Ministry of Science and Technology, Abuja
Macleod WN, Turner DC, Wright EP (1971) The geology of JosPlateau, Vo. 1 General Geology. Geol Surv Niger Bull 32

Nesbitt HW (1979) Mobility and fractionation of rare earth elements during weathering of granodiorite. Nature 279:206-210

Price WE (1974) The relationship between endemic elephantiasis of the lower legs and the local soils and climate. Trop Geogr Med 26(3):225-230

Sutherland RA (2000) Bed sediments associated trace elements in an urban stream, Oahu, Hawaii. Environ Geol 39:611-627

Taylor SR (1964) Abundance of chemical elements in the continental crust. Geochim Cosmochim Acta 28(80):1273-1285

Tomlinson DC, Wilson JG, Harris CR, Jeffrey DW (1980) Problems in the assessment of heavy metals levels in estuaries and the formation of a pollution index. Helgol Wiss Meeresunters 33(1-4):566-575

Tsalha MS, Lar UA, Yakubu TA, Oniku SA (2014) Geophysical investigation of the subsurface fracture zones using vertical electrical sounding in Kassa Volcanic Field (KVF) on the Jos Plateau, North central Nigeria. J Environ Earth Sci 4(10):150-160. www.iiste.org (ISSN 2224-3216 (paper), ISSN 2225-0948 (online))

World Health Organization (WHO) (2004) Water, sanitation and hygiene. http://www.who.int/water-sanitation-health/publications/facts2004/ en/index.html,2007

Zhang GL, Pan JH, Huang CM, Gong ZT (2007) Geochemical features of soils chronosequence developed on basalt in Hainan Island, China. Revista Mexicana de Ciencias Geologicas, 24(2):261-269 